\title{
The use of alveolar corticotomy procedures in orthodontic treatment
}

\author{
Utilizarea corticotomiilor alveolare în tratamentul ortodontic
}

\begin{tabular}{|c|}
\hline $\begin{array}{l}\text { Cristian Niky Cumpătă, Dana Cosac, Tudor Petru Ionescu } \\
\text { Facultatea de Medicină Dentară, Univeristatea „Titu Maiorescu“, Bucureşti, România }\end{array}$ \\
\hline ABSTRACT \\
\hline $\begin{array}{l}\text { Performing alveolar corticotomies shortly before the application of orthodontic forces has been suggested as a meth- } \\
\text { od to improve the dental movement and, consequently, the orthodontic treatment as a whole. The study } \\
\text { evaluate whether alveolar corticotomies can accelerate tooth movements in orthodontic treatment, if they can } \\
\text { broaden the scope of treatment for different types of dento-maxillary abnormalities, reduce the need for dental } \\
\text { extractions and sustain long-term stability. Several techniques have been proposed, although indications, type of } \\
\text { surgery, possible postoperative complications, treatment objectives and patient satisfaction remain unclear. } \\
\text { The purpose of this study was to analyse whether orthodontic treatment time is reduced in patients receiving alveolar } \\
\text { corticotomies. }\end{array}$ \\
\hline Keywords: orthodontic treatment, alveolar corticotomies \\
\hline REZUMAT \\
\hline $\begin{array}{l}\text { Efectuarea corticotomiilor alveolare cu puţin timp înainte de aplicarea forţelor ortodontice este sugerată ca o } \\
\text { metodă de îmbunătăţire a mişcării dentare şi, în consecinţă, a tratamentului ortodontic în ansamblu. Studiul } \\
\text { prezentat a urmărit dacă corticotomiile alveolare pot accelera mişcările dinţilor în cadrul tratamentului orto- } \\
\text { dontic, dacă pot lărgi domeniul de aplicare a tratamentului diferitelor tipuri de anomalii dento-maxilare, dacă } \\
\text { diminuează necesitatea extracţiilor dentare şi dacă pot susţine stabilitatea pe termen lung. Au fost propuse } \\
\text { mai multe tehnici, deşi indicaţile, tipul intervenţiei chirurgicale, eventualele complicaţii postoperatorii, obiec- } \\
\text { tivele tratamentului şi satisfacţia pacientului încă rămân neclare. } \\
\text { Scopul acestui studiu a fost de a analiza dacă se miç̧orează timpul necesar tratamentului ortodontic la pa- } \\
\text { cienţii care beneficiază de corticotomii alveolare. }\end{array}$ \\
\hline
\end{tabular}

Cuvinte cheie: tratament ortodontic, corticomii alveolare

\section{INTRODUCERE}

În ultimele decenii, numărul pacienţilor cu tratament ortodontic, cu preocupări estetice majore şi o durată cât mai scurtă a tratamentului a crescut semnificativ (1). Simultan, progresele substanţiale în domeniul ortodonţiei au lărgit posibilitatea de mişcare potenţială a dinţilor şi au crescut eficienţa tratamentului. În termeni practici pentru un adult, acest lucru poate implica o trecere de la o odontectomie sau o intervenţie de chirurgie ortognată spre o abordare mai conservativă.

Corticotomia este definită ca o procedură chirurgicală în care osul cortical este tăiat, perforat sau modificat mecanic (2). Kole a fost primul care de- scrie în zilele moderne ortodonţia facilitată prin corticotomie. El a folosit termenul „bony-block” pentru a descrie mişcare osoasă după corticotomie (Kole, 1959). Mai târziu, pe baza tomografiei computerizate, Wilcko şi colab. au demonstrat că mişcarea rapidă a dinţilor, asociată cu corticotomia a fost mult mai probabil rezultatul unui proces de demineralizare/remineralizare în concordanţă cu faza iniţială a aşa-numitei accelerări regionale (RAP), caracterizat printr-o creştere a porozităţii osoase corticale şi a turn-overului osului trabecular ca urmare a activităţii osteoclastelor (3).

Această explozie localizată de remodelare a țesuturilor dure este reversibilă şi are ca rezultat oste- 
openia (Frost, 1989). Deoarece osteopenia se caracterizează prin reducere de masa osoasă, dar fără reducerea volumului osos, ingredientul osteoid al osului creşte în timp ce conţinutul mineral scade. Se recomandă ca RAP să înceapă în câteva zile de la operaţie, de obicei atingând un maxim la 1-2 luni (2). Corticotomia alveolară selectivă poate fi utilizată în majoritatea cazurilor în care se foloseşte terapia tradiţională ortodontică fixă. A fost dovedită a fi eficientă în tratamentul malocluziei de clasa I moderată până la severă, în malocluzia de clasa II - necesită uneori expansiune moderată sau extracţie dentară, dar şi în malocluzia uşoara de clasa III (2). Coordonarea strânsă între chirurg şi ortodont este esenţială pentru obţinerea rezultatelor optime.

Scopul acestui studiu a fost de a analiza dacă se micşorează timpul necesar tratamentului ortodontic la pacienţii care beneficiază de corticotomii alveolare şi de a răspunde următoarelor întrebări:

1. Ortodonţia facilitată de corticotomie reduce timpul de tratament la adulţi sănătoşi, comparativ cu ortodonţia convenţională?

2. Care este morbiditatea asociată acestei proceduri?

3. Care este gradul de satisfacţie a pacientului?

\section{MATERIAL ŞI METODĂ}

Studiul descriptiv a fost făcut pe un lot de 16 pacienţi cu anomalii dentomaxilare. Un număr de 8 pacienţi au beneficiat de corticomie alveolară şi 8 pacienţi de tratament ortodontic convenţional. S-au evaluat următorii parametrii: timpul necesar de la aplicarea tracţiunii până la finalizarea mişcărilor dentare şi aplicarea contenţiei unde este cazul, cât şi complicaţiile apărute cum ar fi durere, tumefacţie şi hipersensibilitate dentinară.

Timpul mediu de tratament în cazurile ortodontice uşoare cu corticotomie a fost de 6,1 luni (+/- 1-2 luni); timpul de tratament al grupului de control a fost de 14 luni (+/-2-3 luni).

S-au întocmit acordurile informate ale pacienţilor participanţi la acest studiu împreună cu broşurile informativ-explicative. Fiecare pacient a fost informat asupra introducerii în studiu şi a semnat acordul informat, acesta fiind un criteriu de selecţie a introducerii lui în evaluarea prospectivă.

Criterii de selecţie şi includere a pacienţilor în studiu:
- Pacienţi cu crossbite posterior, incongruenţă dento-alveolară anterioară;

- Fără semne sau simptome de disfuncţie temporo-mandibulară;

- Pacienţi fără extracţii sau anodonţii;

- Pacienţi fără lucrări protetice sau reconstituiri corono-radiculare;

- Pacienţi fără anomalii cranio-maxilo-faciale;

- Fără intervenţii chirurgicale orale;

- Fără boală parodontală.

Criterii de excludere:

- Terapie cu antiinflamatoare steroidiene;

- Terapie cu bifosfonaţi;

- Tratament anticoagulant;

- Afecţiuni sistemice.

Pacienţii au fost împărţiţi în 2 loturi: lotul nr.1 - pacienţi cu corticotomii vestibulare -8 cazuri şi lotul nr. 2 - pacienţi cu tratament ortodontic convenţional -8 cazuri.

\section{Protocol terapeutic}

Lotul nr. 1: 4 pacienţi cu angrenaj invers posterior si 4 pacienţi cu incongruenţă dento-alveolară anterioară. 7 intervenţii au fost efectuate la maxilarul superior şi una singură la mandibulă (caz de incongruenţă dento-alveolară). Lotul nr. 2: 8 pacienţi cu înghesuiri dento-alveolare moderate în zona frontală care nu necesită extracţii şi tratate prin expansiune şi stripping.

Necesar de spaţiu omogen între cele 2 loturi. Toţi pacienţii au beneficiat de anestezie locală sau loco-regională. În toate cazurile s-a creat un lambou vestibular cu grosime totală $(1,4,5,6,7)$. Corticotomiile au fost realizate cu freze fissure şi / sau cu freze sferice $(4,6,8,9,10)$ şi în 2 cazuri utilizând dispozitive piezoelectrice (6).

Liniile de corticotomie au fost verticale - mezial de cel mai anterior dinte şi distal de cel mai posterior dinte, utilizate atât in zona anterioară cât si în regiunea posterioară a maxilarelor $(1,5,6,11)$. Corticotomia a interesat numai osul cortical vestibular. Corticotomiile au fost efectuate într-o singură etapă (5).

\section{REZULTATE}

Timpul mediu total de tratament ortodontic facilitat prin corticotomie alveolară a fost 6,1 luni (+/- 


\section{LOT 1}

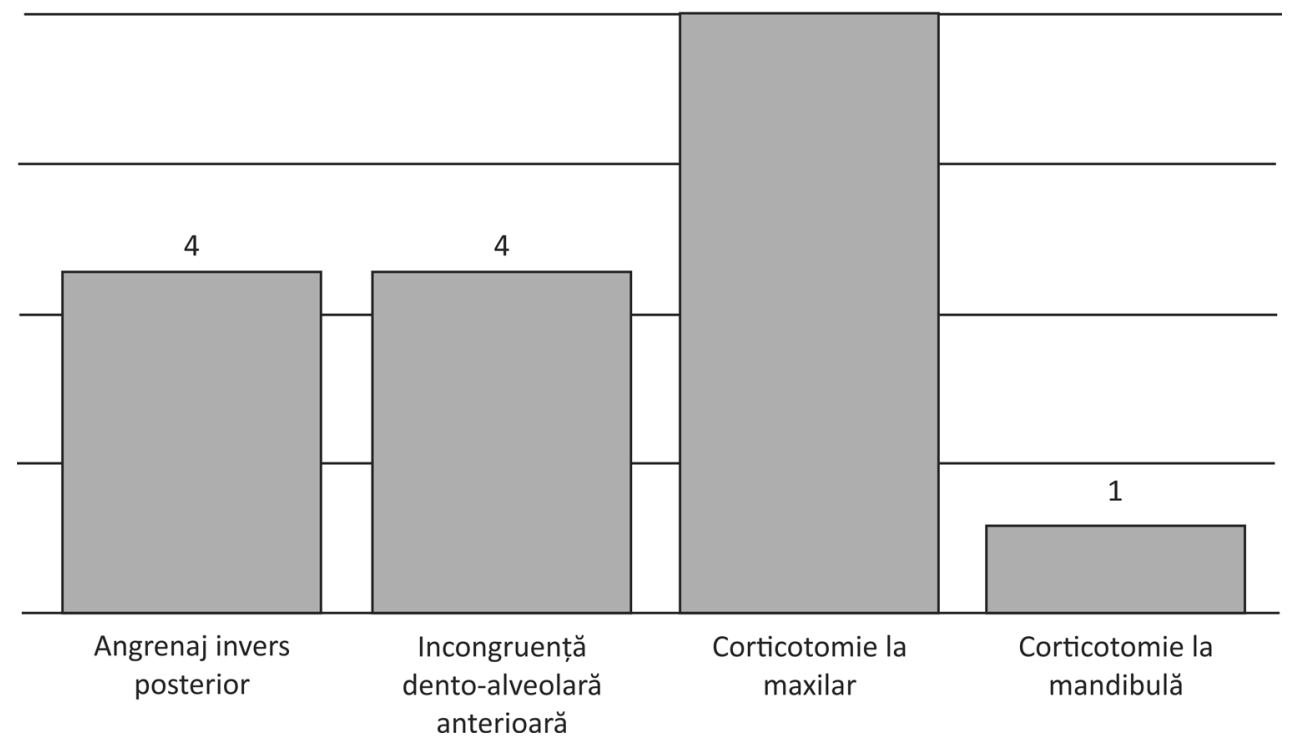

FIGURA 1. LOT 1 - repartiția tipului de anomalie dentară şi localizarea intervenției chirurgicale

1-2 luni). În mod normal, pentru tratamentul ortodontic convenţional, fără corticotomie alveolară, la lotul nr.2 de pacienţi, durata medie este de 14 luni (+/-2-3 luni). Nu a fost raportată nicio complicaţie parodontală sau pierderea vitalităţii dinţilor. Doar un singur pacient a raportat hipersensibilitate dentinară care s-a recuperat fără complicaţii după 5 săptămâni. Doi pacienţi au raportat dureri şi tumefacţie moderată primele 5 zile postoperator.

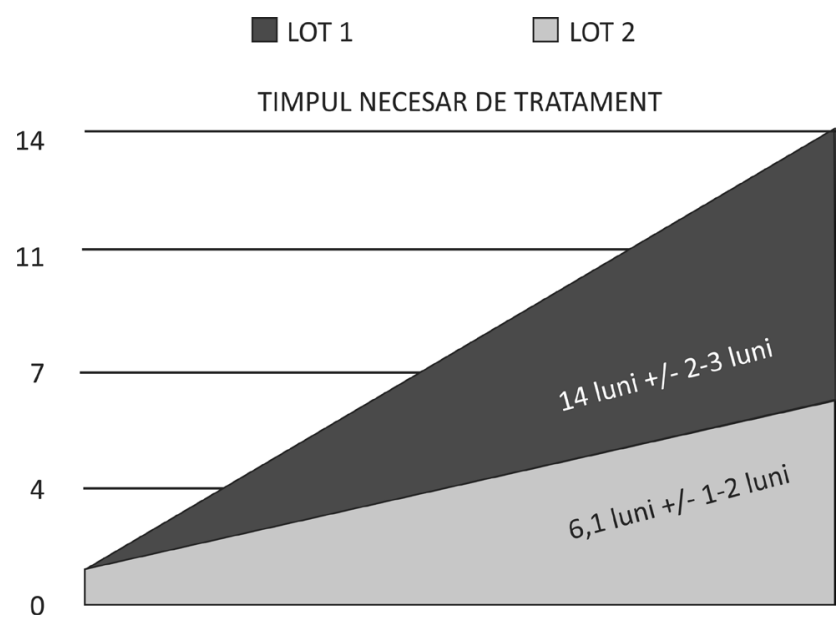

FIGURA 2. LOT 1 - procentul complicațiilor apărute după corticotomia alveolară

Evaluarea calităţii: gradul de satisfacţie al pacientului a fost ridicat datorită timpului scăzut al tratamentului şi datorită rezultatului obţinut.

\section{Complicații postcorticotomie LOT 1 (8 pacienți)}

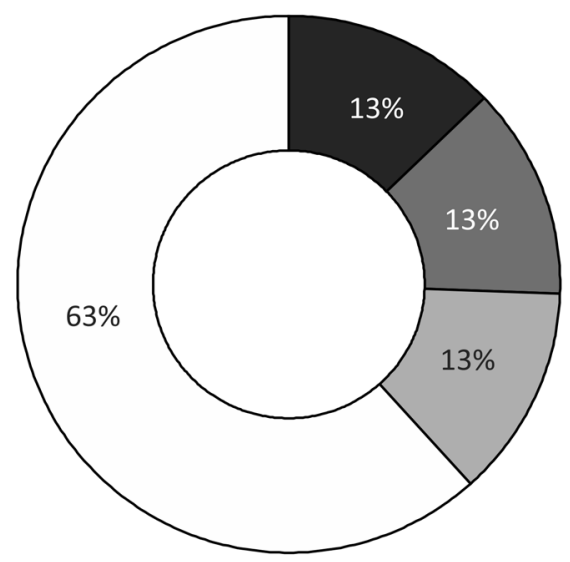

Hipersensibilitate dentară

Durere postcorticotomie

Tumefacție moderată

$\square$ Fără complicații

FIGURA 3. Timpul necesar de tratament pentru cele două loturi

\section{DISCUȚII}

Pacienţii au fost selectaţi pe baza unor criterii stricte. $\mathrm{Cu}$ toate acestea, există alte rapoarte de caz, descrieri ale cercetătorilor, cum ar fi seria de cazuri publicate de Wilcko, Dibart Vercelloti şi Bertossi $(3,12,13,14)$ care descriu cele mai frecvente şi actuale tehnici ortodontice. Există multe indicaţii pentru utilizarea corticotomiilor alveolare în tratamentul ortodontic. Acestea pot fi folosite pentru a 
accelera corecţiile tratamentul ortodontic; în ansamblu - pentru a facilita punerea în aplicare a mişcărilor ortodontice şi a spori corecţia malformaţiilor moderate şi severe. Timpul de tratament a fost scurtat $(4,6,7,8,9)$. Timpul mediu de tratament la pacienţi lotului nr. 2 care au suferit un tratament ortodontic convenţional, este de obicei de 14 luni, în timp ce în grupurile de intervenţie (lotul nr. 1) a fost de 6,1 luni.

Unele studii nu au raportat timpul total de tratament, $(1,4,11)$ dar au măsurat rata de mişcare a dinţilor şi au dovedit ca mişcarea dentară a fost mai rapidă în grupurile de corticotomie decât în grupurile de control (4) sau că rezultatele obţinute ar fi mai greu de realizat fără utilizarea corticotomiilor.

Toate tehnicile de corticotomie se concentrează în primul rând pe slăbirea rezistenţei la interfaţa corticală os-dinte. Kole a sugerat că cea mai mare rezistenţa la mişcarea dentară este generată de osul cortical alveolar (15). O osteotomie osoasă mică a maxilarului induce o creştere regională, dar nu sistemică, creşterea ratei de turnover al osului alveolar şi a porozităţii osoase.

Doi pacienţi au raportat disconfort crescut şi durere asociată intervenţiei chirurgicale în primele 5 zile postoperatorii. Ca şi în alte studii pacienţii au simţit că procedura a fost mai puţin traumatică decât extracţia dinţilor (8).

Corticotomia verticală a fost utilizată la tot grupul de pacienţi, fiind efectuată atât în zona anterioară $(1,8,9)$ cât şi posterioară a maxilarelor $(1$, $5,6,7,10,11)$. Toţi autorii au realizat corticotomiile prin osul cortical până la medulară fără fractura sau interesarea acesteia. Pentru corticotomie cel mai frecvent se utilizează frezele fissure sau sferice. Piezo-chirurgia conferă siguranţă corticotomiei în jurul rădăcinilor (13). Regenerarea osoasă este mai probabilă şi vindecarea pare a fi mai rapidă (16).

Corticotomia realizată cu freze are un potenţial ridicat de afectare a a dinţilor în apropierea rădăci- nilor şi afectarea regenerării osoase ca rezultat al căldurii excesive. În 2012, Casseta şi colab. au raportat că nu există o diferenţă semnificativă statistic când ne referim la durata totală a tratamentului atunci când se compară utilizarea dispozitivelor piezoelectrice versus freze, iar în ambele grupuri au fost prezente disconfort şi durere indiferent de tehnica de corticotomie utilizată.

Corticotomia poate duce la recesiune gingivală (16). $\mathrm{Nu}$ există retracţii sau pungi parodontale. $\mathrm{Nu}$ a fost raportată pierderea vitalitatea dinţilor. Un singur pacient a fost raportat cu hipersensibilitate dentinară care s-a recuperat fără complicaţii după 5 săptămâni. În acest studiu au fost puţine complicaţii, iar morbiditatea a fost scăzută până la moderată. A fost raportat un rezultat bun al percepţiei pacientului şi un nivel scăzut al disconfortului în timpul şi după intervenţia chirurgicală.

\section{CONCLUZII}

Există un interes crescut în utilizarea corticotomiilor alveolare ca adjuvant la tratamentul ortodontic datorat unei înţelegeri mai profunde a efectelor sale şi ale unor dovezi bazate pe cercetare. Stimularea biologică produsă de corticotomii este reflectată în structura osoasă trabeculară şi asigură astfel posibilitatea de a spori anumite mişcări ortodontice.

Designul corticotomiilor şi perforaţiilor la nivelul corticalei osoase par a fi irelevante, dar trebuie perforat stratul cortical osos, iar extinderea în medulară trebuie să fie minimă. În contextul selecţiei adecvate a pacienţilor, corticotomiile alveolare pot îmbunătăţi calitatea şi durata tratamentelor ortodontice.

\section{Menţiune}

Toţi autorii au contribuţie egală în realizarea acestui articol.

\section{BIBLIOGRAFIE}

1. Hernandez-Alfaro F, Guijarro-Martinez R. On a definition of the appropriate timimg for surgical intervention in orthognatic surgery. Int J Oral Maxilofac Surg. 2014, 43:846-55.

2. Murphy NC et all. Orthodontically Driven Corticotomy: Tissue Engineering to Enhance Orthodontic and Multidisciplinary Treatment. Hoboken, Wiley-Blackwell, 2014, pp.1-39.

3. Wilcko et all. Accelerated osteogenic orthodontics technique: a 1-a stage surgically facilitated rapid orthodontic technique with alveolar augmentation. J Oral Maxilofac Surg 2009; 67)10):2149-59.
4. Aboul-Ela SMBE, El-Beialy AR, El-Sayed KMF, El-Mangoury NH, Mostafa YA. Miniscrew implant-supported maxillary canine retraction wit hand without corticotomy-facilitated orthodontics. Am. J Ortho Dent Ortho 139:252-259, 2011.

5. Choo HR, Heo HA, Yoon Hj, Chung KR, Kim SH: Treatment outcome analysis ofspeedy surgical orthodontics for adults with maxillary protrusion. Am J Ortho Dent Ortho 140(6): e251 -e262, 2011.

6. Ahn HW, Lee DV, Park YC, Kim SIL, Chung KR, Nelson GR. Accelerated decompensation of mandibular incisors in surgical 
skeletal class III patients by using augmented corticotomy: a preliminary study. Am J Ortho Dent Ortho 142(2)5 199-206, 2012.

7. Bhattacharya P Bhattacharya H, Anjum A, Bhandari R. Agarwal DK, Gupta A, et al: Assessment of corticotomy facilitated tooth movement and changes in alveolar bone thickness - a CT scan study.J Clin Diagn Res 8(10): ZC26-ZC30, 2014.

8. Gantes B, Rathbun E, Anholm M: Effects on the periodontium following corticotomy-facilitated orthodontics. Case reports. J Periodont 61: 234-238, 1990.

9. Wang B, Shen GF, Fang B, Yu HB, Wu Y: Augmented corticotomyassisted presurgical orthodontics of class III malocclusions: a cephalometric and cone-beam computed tomography study. J Craniofac Surg 24:1886-1890, 2012.

10. Al-Naoum F, Hajeer MY, Al-Jundi A: Does alveolar corticotomy accelerate orthodontic tooth movement when retracting upper Canines? A split-mouth design randomized controlled trial. J Oral Maxillofac Surg 72: 1880-1889, 2014.

11. Ma ZG, Yang C, Xi OM, Ye ZX, Zhang SK, Abdelrehem A: A novel surgical technique for augmented corticotomy - assited orthodontics: bone grafting with periosteum. J Oral Maxillofac Surg. 74(1):170-180, 2016.
12. Dibart S, Sebaoun JD, Sunnenian J: Piezocision: a minimally invasive periodontally accelerated orthodontic tooth movement procedure. Compen Cont Edu Dent 30(5): 342-350, 2009.

13. Vercelloti T, Podesta A: Orthodontic microsurgery, a new surgically guided technique for dental movement. Int J Periodontics Restor Dent 27:325-331, 2007

14. Bertossi D, Vercelotti T, Podesta A, Nocini PF: Orthodontic microsurgery for rapid dental repositioning in dental malposition. $\mathrm{J}$ Oral Maxillofac Surg 69:747-753, 2011.

15. Kole $\mathrm{H}$ : Surgical operations of the alveolar ridge to correct occlusal abnormalities. Oral Surg Oral Med Oral Pathol 12: 515-529,1959

16. Wilco MT, Wilco WM, Bissada NF:An evidence-based analyses of periodontally accelereted orthodontic and osteogenic techiques: a synthesis of scientific perspectives. Semin Orthod 14:305-316, 2008. 